\title{
PROBLEM PENGEMBANGAN KREATIVITAS HAKIM DI TENGAH INTERVENSI KEKUASAAN DAN MAFIA PERADILAN (Bercermin pada Pemikiran Filsafat Hukum Roscoe Pound)
}

\author{
Abmad Syafi'i SJ
}

\section{Abstract}

Roscoe Pound stated that law must be functioned as a social control and social engineering so there should be a space for them to be more creative on applying the laws. Almost all of law bolders have the duty realizing the ideal of law completely. Among other law bolders the position of the judge is special. The judge basically is the representation of God in the world to uphold the law and justice. Nevertheless placing the judge as law maker is not always easy, because they are only one of practical caretakers of law which their independence and integrity is often covered by some internal and external interests.

Kata kunci: Social Control, Independensi, Mafia Peradilan

\section{A. Pendahuluan}

Terkait dengan penegakan hukum (law enforcement) ada adagium yang berbunyi "fiat justicia et pareat mundus" (meskipun dunia akan runtuh hukum harus tetap ditegakkan). Adagium

- Alumni Program Pascasarjana UIN Sunan Kalijaga Yogyakarta Program Studi Hukum Islam. Sekarang aktif sebagai staf pengajar di Fakultas Syari'ah INSURI dan Dosen Luar Biasa STAIN Ponorogo. 
tersebut memberikan gambaran bahwa selain hukum harus ditegakkan, juga akan memberikan kepastian hukum, kemanfaatan, dan keadilan bagi para pencari keadilan. Kepastian, kemanfaatan dan keadilan hukum tidak hanya akan memberikan perlindungan bagi pencari keadilan tetapi juga akan dapat menciptakan ketertiban dalam masyarakat. Keadilan merupakan bagian yang tidak terpisahkan dari hukum itu sendiri. Hukum pada dasarnya berintikan keadilan. Gustav Radbruch menyatakan bahwa keadilan merupakan salah satu nilai dasar dari hukum. ${ }^{1}$

Semua aparat penegak hukum ${ }^{2}$ berkewajiwan mewujudkan cita hukum secara utuh, yakni: keadilan, kemanfaatan menurut tujuan dan kepastian hukum. Diantara para penegak hukum yang lainnya, posisi hakim adalah istimewa. Hakim adalah konkritisasi hukum dan keadilan yang abstrak, bahkan ada yang menggambarkan hakim sebagai wakil Tuhan di bumi untuk menegakkan hukum dan keadilan.

Beberapa tugas hakim yang telah digariskan dalam UU No. 4 Tahun 2004 tentang Kekuasaan Kehakiman antara lain: Pertama, tugas dalam bidang peradilan (teknis yudisial) diantaranya adalah: (a) menerima memeriksa dan mengadili serta menyelesaikan setiap perkara yang diajukan kepadanya; (b) mengadili menurut hukum dengan tidak membedakan orang (pasal 5 ayat 1); (c) membantu para pencari keadilan dan berusaha sekeras-kerasnya mengatasi hambatan dan rintangan demi tercapainya peradilan yang sederhana, cepat dan biaya ringan (pasal 5 ayat 2); tidak boleh menolak untuk memeriksa dan mengadili suatu perkara yang diajukan dengan dalih bahwa hukumnya tidak/kurang jelas, melainkan wajib memeriksa dan mengadilinya (pasal 16 ayat 1 ).

Kedua, tugas yuridis, yaitu memberi keterangan, pertimbangan dan nasihat-nasihat tentang soal-soal hukum kepada

\footnotetext{
${ }^{1}$ Satjipto Rahardjo, Ilmu Hukum (Bandung: Alumni, 1986).

${ }^{2}$ Dalam konsep "Catur Wangsa", Hakim, Jaksa, Polisi dan Advokad (lanyers) merupakan faktor penting dalam penegakan hukum. Lihat Ari Hernawan, "Reposisi Fungsi Advokad dalam Proses Penegakan Hukum," dalam Asy-Syirab, 36, 2 (2002), hal. 98-107.
} 
lembaga negara lainnya apabila diminta (pasal 27). Ketiga, tugas akademis ilmiah dalam melaksanakan tugas pokoknya, yaitu hakim wajib menggali, mengikuti dan memahami nilai-nilai hukum dan rasa keadilan yang hidup dalam masyarakat (pasal 28 ayat 1$)$.

Namun amanah ideal yang diberikan oleh undang-undang kepada hakim tersebut di atas belum sepenuhnya membumi, karena kenyataan yang tak terbantahkan yang dapat kita rasakan saat ini adalah bahwa kondisi penegakan hukum (law inforcement) sudah mencapai titik nadir. Masyarakat tidak menghormati hukum. Wibawa penegak hukum (termasuk hakim) juga kian merosot sehingga hukum tidak lagi dapat memberikan rasa aman dan tenteram. Hukum tidak dapat menyelesaikan berbagai persoalan yang mengedepan dalam dinamika masyarakat dan kepastian hukum semakin dipertanyakan. ${ }^{3}$ Hukum bertambah "lumpuh" menghadapi berbagai pelanggaran dan kejahatan yang terjadi sehingga keadilan menjadi utopia dalam masyarakat. Masyarakat semakin tidak terlindungi, tersubordinasi serta tereksploitasi.

Adanya fenomena amuk masa dan main hakim sendiri secara membabi buta merupakan indikasi dari rendahnya tingkat kepercayaan masyarakat. Memang bukan menjadi rahasia umum lagi, bahwa di Indonesia penegakan hukum (law enforcement) sangat lemah. Hampir sepanjang sejarah Indonesia merdeka, masalah penegakan hukum senantiasa menjadi sorotan. Lebih-lebih pada era reformasi ini, dimana kesadaran akan penegakan hukum semakin tinggi, sorotan itu menjadi lebih tajam lagi. Sorotan tadi muncul dari adanya rasa kekecewaan terhadap buruknya "performance" penegak hukum dalam menegakkan hukum di Indonesia. Mereka yang kecewa tidak hanya orang Indonesia, melainkan juga masyarakat Internasional.

\footnotetext{
${ }^{3}$ Lihat Esmi Warassih, Pemberdayaan Masyarakat Dalam Menujudkan Tujuan Hukum (Proses Penegakan Hukum dan Persoalan Keadilan) (Semarang: Badan Penerbit Universitas Diponegoro, 2001).
} 
Kekecewaan terhadap penegakan hukum muncul dalam berbagai bentuk. Ada yang berupa wacana, seperti munculnya istilah "mafia peradilan", pemlesetan KUHP menjadi "kasih uang habis perkara", sindiran bahwa Indonesia juara korupsi tanpa koruptor dan lain sebagainya. Bagi mereka yang berkuasa mampu "mempermainkan", sedang bagi rakyat kecil "dipermainkan" oleh hukum. Sindiran Oliver Goldsmith dalam karyanya "The Laws Grind the Poor, the Rich men Rule the Law,"4 menjadi niscaya untuk direnungkan kembali.

Dalam kajian ini, penulis hendak mengurai problem pengembangan kreativitas hakim yang nota bene sebagai pembentuk hukum dan salah satu pilar penegak hukum dengan mengelaborasi pemikiran filsafat hukum Roscou Pound, salah seorang proponent utama madzhab Sociological Jurisprudence.

\section{B. Prisma Pemikiran Roscoe Pound}

\section{Hukum dan Realitas Sosial}

Di Amerika Serikat, Roscoe Pound, dengan filsafat hukumnya, tampil untuk mengartikulasikan kajian sosial terhadap hukum secara lebih rinci yang kemudian bahkan menjadi suatu aliran tersendiri dalam ilmu hukum yang disebut dengan "sociological jurisprudence" tersebut. ${ }^{5}$ Pada awal abad ke XX, Pound telah menggunakan istilah "sociological jurissts", yaitu pada saat menjelaskan apa yang menjadi tugas intelektual mereka. Pernyataan Pound tersebut adalah sebagai berikut: ${ }^{6}$

${ }^{4}$ Rene David, Major Legal System in The World Today (London: Stevans \& Sons, 1995), hal. 14.

${ }^{5}$ Dalam kaitannya dengan ini, Pound menjelaskan perbedaan antara sosiologi hukum dengan sociological jurisprudence. Menurut Pound perbedaan di antara keduanya adalah jika sociological jurisprudence merupakan suatu madzhab dalam filsafat hukum yang mempelajari pengaruh timbal balik antara hukum dan masyarakat dan sebaliknya, maka sosiologi hukum adalah cabang sosiologi yang mempelajari pengaruh masyarakat terhadap hukum dan sejauh mana gejala-gejala yang ada dalam masyarakat itu dapat mempengaruhi hukum tersebut, disamping juga diselidiki sebaliknya pengaruh hukum terhadap masyarakat. Lihat Pound, "Kata Pengantar", dalam Geoges Gurvitch, Sosiologi Hukum, teri. Sumantri Mertodipuro (Jakarta: Bhratara, 1988), hal. x-xi.

"Lihat Roscoe Pound, "The Scope and Purpose of Sociological Jurisprudence", 
The main problem to which sociological jurists are addressing themselves today is to enable and to compel law-making, and also interpretation and application of legal rules, to take more account, and more intelegent account, of the social facts upon which law must proceed and to which it is to be applied...

Dari pernyataan Pound tersebut, terlihat jelas bahwa filsafat hukum Pound tidak menempatkan hukum pada posisi steril yang terisolasi dari lingkungan sosialnya. Studi hukum, bagi Pound, bukanlah mempelajari hukum perundang-undangan secara hitamputih, yang hanya melihat ke dalam susunan internal sistem hukum secara logis-rasional, melainkan juga melihat efektivitas hukum. Dengan membicarakan efektivitas hukum ini, Pound telah berusaha mengaitkan hukum kepada lingkungan sosialnya, yang dalam filsafat Radbruch disebut sebagai nilai kegunaan hukum.

Mazhab sociological jurisprudence ini mengetengahkan tentang pentingnya "hukum yang hidup" (living law) di dalam masyarakat. Bahkan kelahirannya, menurut beberapa anggapan, merupakan suatu sinthesis dari pada thesanya Positivisme hukum dan antithesanya Mazhab sejarah. Dengan demikian, sociological jurisprudence berpegang kepada pendapat pentingnya baik akal maupun pengalaman.

Sebelum mengeksplorasi lebih jauh pemikiran Pound, alangkah baiknya penulis paparkan terlebih dahulu mengenai konsepsi Pound terhadap hukum itu sendiri. Pembicaraan mengenai "apa hukum itu?" merupakan sasaran utama filsafat hukum. ${ }^{7}$ Semua buku mengenai filsafat hukum dan ilmu hukum selalu memuat pertanyaan ini. Namun hampir semua jawabannya

dalam Ervin H. Pollack, Jurisprudence: Principles and Applications (Ttp.: The Ohio State University Press, 1979), hal. 643.

7 Theo Huijbers, Filfasat Hutum dalam Lintasan Sejarab (Yogyakarta: Kanisius, 1982), hal. 271. 
menegaskan akan sulitnya membuat sebuah definisi yang tepat. Pada waktu membicarakan ilmu kimia, kita tidak pernah mengawali pertanyaan "apa kimia itu?" Demikian juga dengan disiplin ilmu yang lain.

Adalah menarik apa yang menjadi pandangan Pound dalam masalah ini. Pound berangkat dari sisi lain, bukannya mengawali dengan pernyataan bahwa definisi tentang hukum itu tidak tepat. Menurutnya, esensi hukum (nature of law) telah menjadi inti perdebatan di dalam ilmu hukum (Jurisprudence) sejak para filsuf Yunani memulai perdebatan mengenai dasar kekuasaan hukum (law's autbority). Namun tujuan hukum (the end of law) telah diperdebatkan lebih banyak di dalam politik daripada di dalam ilmu hukum.

Menurut Pound, dalam tingkatan equity ${ }^{8}$ dan hukum alam (natural law), teori-teori yang umum mengenai esensi hukum tampak menjawab pertanyaan hukum. Pound mengemukakan dua belas konsep mengenai apa hukum itu, yang bisa dibedakan antara satu dengan lainnya. ${ }^{9} \mathrm{Ke}$ dua belas konsep dimaksud adalah: Pertama, ide atau konsep mengenai aturan atau seperangkat aturan yang datang dari Tuhan (bersifat ketuhanan) untuk mengatur prilaku manusia, seperti hukum Nabi Musa, dan Nabinabi yang lain. Kedua, ide atau konsep mengenai hukum sebagai tradisi dari adat yang tua yang telah membuktikan akan diterima oleh tuhan-tuhan, sehingga orang-orang yang mengikutinya akan melewati jalan dengan selamat. Ini adalah untuk orang-orang primitif. Dalam konteks ini hukum adalah "bentuk kebiasaan atau bentuk yang terekam dari ajaran-ajaran di mana adat

${ }^{8}$ Equity bisa berarti "justice" (keadilan). Di dalam sejarahnya, di Inggris, equity berkembang menjadi jenis hukum yang terpisah, sebagai tanggapan terhadap ketidakmampuan hukum adat di pengadilan untuk menyediakan pengobatan terhadap setiap luka. Lebih lanjut muncul istilah: "equity suffers not a right with out remedy "atau "equity follows the law", yang berarti bahwa equity akan mewujudkan alat untuk mewujudkan hasil yang dibenarkan ketika prosedur hukum (yang umum) tidak bisa bekerja. Lihat Steven H. Gifis, Law Dictionary (New York: Barron's Educational Series, Inc., 1984), hal. 163.

'Roscoe Pound, An Introduction to the Pbilosopby of Lan (New Brunswick \& London: Transaction Publishers, 1999), hal. 46-54. 
dipertahankan dan di ekspresikan”. Ketiga, ada kaitannya dengan yang kedua, hukum diartikan sebagai "kebijaksanaan yang terekam dari orang-orang yang bijak yang telah mempelajari jalan yang aman atau jalan yang disetujui Tuhan untuk tingkah laku manusia”. Ini meliputi keputusan dan tindakan atas dasar kebiasaan yang kemudian direduksi menjadi sebuah kumpulan tulisan dalam aturan hukum orang primitif. Oleh karena itu, hukum Athena pada abad ke IV SM dapat masuk dalam pengertian hukum ketiga ini.

Keempat, hukum dipahami sebagai sistem dasar yang ditemukan secara filosofis yang dapat mengekspresikan esensi pokok sesuatu, di mana setiap orang harus bertindak sesuai dengannya. Termasuk dalam pengertian seperti ini adalah model pemberi fatwa hukum di Romawi (Roman Jurisconsult). Pengertian kedua dan ketiga juga dapat masuk ke dalam kategori ini yang sekaligus mencakup kemauan atau perintah rakyat Romawi, sehingga ketiga hal tersebut (tradisi/adat, rekaman kata-kata orang bijak, dan kemauan rakyat) merupakan deklarasi filosofis untuk kemudian menjadi sebuah ketentuan hukum. Kelima, hukum dipahami sebagai kumpulan deklarasi mengenai aturan moral yang kekal dan tidak berubah. Ini berarti hukum dianggap identik dengan ketentuan moral universal. Keenam, hukum dipahami sebagai kumpulan persetujuan atau keputusan orang-orang dari organisasi/partai politik di masyarakat. Definisi ini adalah versi demokratis yang mempunyai identitas ketentuan rules of law. Meskipun hukum di sini merupakan produk para politisi, namun akan (harus) selalu ada muatan kewajiban moral tentang konsep janji (promise) yang akan selalu ditunjukkan kepada masyarakat bahwa para politisi tersebut akan selalu menjaga keputusankeputusan yang menjadi hukum tersebut.

Ketujuh, hukum dipahami sebagai refleksi ketentuan yang bersifat ketuhanan untuk mengatur dunia. Yaitu sebuah refleksi untuk mengatur apa yang "sebaiknya" dijalankan oleh umat manusia sebagai ketentuan moral -sekedar untuk dibedakan 
dengan "keharusan" dalam penciptan Tuhan. Teori inilah yang kemudian dikembangkan oleh Thomas Aquinas yang juga sangat popular pada abad ke-17, bahkan juga sampai kini masih ada gaungnya. Kedelapan, hukum dipahami sebagai kumpulan perintah dari penguasa yang mempunyai kedaulatan dan otoritas politik agar bagaimana orang-orang bertindak. Dapat dimasukkan dalam pemahaman teori ini konsep juri pada Romawi dan paham hukum positif pada masa klasik. Dalam kasus kerajaan Romawi, maka sang raja adalah orang yang mempunyai kedaulatan dan otoritas sekaligus yang mempunyai kekuasaan untuk memaksakan hukum. Meskipun pada masa kerajaan Romawi raja mempunyai kekuasaan hukum yang penuh, namun masuk ke teori ini kedaulatan hukum yang ada di tangan parlemen, sejak munculnya supremasi parlemen di Inggris abad ke-17; dan bahkan juga sampai pada kedaulatan parlemen pada revolusi Amerika dan pada revolusi Perancis. Kata kunci di sini adalah bahwa hukum merupakan produk kekuasaan politik dari sistem bentuk perintah raja sampai dengan sitem legislatif. Kesembilan, satu gagasan yang menganggap hukum sebagai satu sistem pemerintah ditemukan oleh pengalaman manusia yang menunjukkan, bahwa kemampuan tiap manusia perseorangan akan mencapai kebebasan sesempurna mungkin yang sejalan dengan kebebasan serupa itu pula yang diberikan kepada kemauan orang-orang lain. Gagasan ini yang dianut dalam salah satu bentuk oleh mazhab sejarah, telah membagi kesetiaan sarjana hukum kepada teori hukum sebagai perintah dari pemegang kedaulatan, dan hal ini terjadi hampir di sepanjang abad yang lalu. Menurut anggapan pada masa itu, pengalaman manusia yang menemukan prinsip hukum ditentukan dengan suatu cara yang tak dapat dielakkan.

Kesepuluh, orang menganggap hukum itu sebagai satu sistem asas-asas, yang ditemukan secara filsafat dan dikembangkan sampai pada perinciannya oleh tulisan-tulisan sarjana hukum dan putusan pengadilan, yang dengan perantaraan tulisan dan putusan 
itu kehidupan lahir manusia diukur dengan akal, atau pada taraf lain, dengan tulisan dan putusan itu kemudian tiap orang yang bertindak diselaraskan dengan kehendak orang lain. Cara berfikir ini muncul dalam abad ke 19 sesudah ditinggalkannya teori hukum alam dalam bentuk yang mempengaruhi pikiran hukum selama dua abad, dan filsafat diminta untuk memberikan satu terhadap kritik susunan sistematik dan perkembangan detail. Kesebelas, hukum dipahamkan orang sebagai sekumpulan atau sistem kaidah yang dipikulkan atas manusia di dalam masyarakat oleh satu kelas yang berkuasa untuk sementara buat memajukan kepentingan kelas itu sendiri, baik dilakukan dengan sadar maupun tidak sadar. Kedua belas, hukum dipahami sebagai perintah dari undang-undang ekonomi dan sosial yang berhubungan dengan prilaku manusia di dalam masyarakat yang ditemukan oleh pengamatan, dinyatakan dalam perintah yang disempurnakan oleh pengamatan manusia mengenai apa yang akan terpakai dan apa yang tidak terpakai di dalam penyelenggaraan pengadilan. Teori tipe ini terdapat pada akhir abad ke-19, tatkala orang mulai mencari dasar fisik dan biologis yang dapat ditemukan oleh pengamatan dan bukan lagi dasar metafisik, yang ditemukan oleh perenungan filsafat.

Dari dua belas konsep hukum yang dipaparkan Pound di atas, dapat disimpulkan bahwa sumber-sumber hukum menurut Pound yaitu: kebiasaan; religi; ide-ide moral dan filosofis; putusan pengadilan (adjudication); diskusi ilmiah dan undang-undang.

Dalam uraiannya lebih lanjut, Pound berpendapat bahwa hukum itu sebagai satu lembaga sosial yang bertujuan untuk memuaskan kebutuhan masyarakat yang beradab. Dalam hal ini Pound menyatakan: ${ }^{10}$

I am content to think of law as a sosial institution to satisfy social wants -the claims and demands involved in the existence of civilized society-by giving effect to as much as we may with the least sacrifice,

${ }^{10}$ Lihat ibid., hal. 85. 
so far as such wants may be satisfied or such claims given effect by an ordering of buman conduct through politically organized society.

Dari pernyataan tersebut, jelas terlihat bahwa ia berupaya mengartikulasikan kajian sosial terhadap hukum serta mengkaji efek sosial yang aktual dari doktrin dan institusi hukum. Jadi, bagi Pound, hukum tidak hanya dapat dilihat sebagai bangunan stereotip yang abstrak, sebagai peraturan-peraturan yang steril dari konteks sosial. Pound pada dasarnya hendak melihat hukum, institusi hukum, prosedur hukum dalam gambar sosialnya yang penuh, yang berarti memasukkan dimensi kemanusiaan dan sosial yang penuh ke dalamnya.

Selanjutnya Pound menegaskan bahwa untuk dapat memuaskan kebutuhan atau tuntutan dan keinginan manusia, maka hukum harus memainkan peranannya sebagai kontrol sosial (social control) dan rekayasa sosial (social engineering). Dalam kaitannya dengan ini, Pound menyatakan: ${ }^{11}$

For present purposes I am content to see in legal bistory the record of continually wider recognizing and satisfying of buman wants or claims or desires through social control; a more embracing and more effective securing of sosial interests; a continually more complete and effective elimination of waste and precluding of friction in buman enjoyment of the goods of existence -in short, a continually more efficacious social engineering.

Dalam suatu formula, Pound bahkan melukiskan bahwa tugas pokok pemikiran modern mengenai hukum adalah tugas "rekayasa sosial" untuk membangun suatu struktur masyarkat agar secara maksimal mencapai kepuasan akan kebutuhan-kebutuhan, dan meminimalisasi benturan-benturan dan pemborosan. ${ }^{12}$

${ }^{11}$ Lihat Ibid. Bandingkan Pound, Tugas Hukum, hal. 10, 20,31; idem, Interpretation of Legal History (USA: Holmes Beach, Florida, 1986), hal. 164.

${ }^{12}$ Formula ini dinyatakan oleh Pound dalam karyanya "Interpretations of Legal History", bab 7; juga dalam Pound, An Introduction to the Pbilosopby, hal. 85. Bandingkan R.W.M. Dias, Jurisprudence (London: Butterworths, 1976). 
Selanjutnya, untuk me-landing-kan konsep hukum dalam ranah sosial, Pound menawarkan beberapa langkah operasional bagi penerapan hukum dalam mengadili suatu perkara, yaitu: ${ }^{13}$ (1) Menemukan hukum, yakni menentukan aturan atau ketentuan yang mana dari sekian banyak aturan atau kaidah (rules) yang terdapat dalam sistem hukum yang ada untuk kemudian diterapkan. Jika memang tidak ditemukan suatu aturan yang dapat diterapkan terhadap suatu kasus, maka harus digunakan analogi terhadap atauran yang sudah ada. (2) Menafsirkan aturan yang dipilih atau ditentukan. Yakni, menentukan arti aturan tadi sebagaimana mestinya, dibarengi dengan melihat cakupan arti yang dikehendakinya. (3) Menerapkan aturan yang telah ditemukan dan ditafsirkan tadi terhadap kasus yang ada di tangan. Dengan proses seperti ini, seorang hakim akan dapat menerapkan hukum dengan baik, tidak asal mengambil aturan yang ia dapatkan dengan acak.

Dari tiga langkah operasional tersebut dapat dipahami bahwa dalam konsepsi Pound hakim tidak hanya menerapkan undang-undang untuk semua kasus yang dihadapinya. Bagi Pound hakim harus diberikan ruang diskresi (kebebasan) yang luas dalam menerapkan hukum dan aturan hukum hanya merupakan aturan umum bagi hakim. Di sini tampaknya Pound telah memberikan solusi bagi problem kreativitas hakim sebagai pembentuk hukum.

Sebagai salah satu proponent utama mazhab sociological jurisprudence, Pound, meskipun pandangannya sangat luas, lebih mengutamakan tujuan-tujuan praktis. Hal ini tampak dalam konsepnya tentang "hukum sebagai alat pengubah masyarakat". Alat pengubah masyarakat yang dimaksudkan oleh Pound, dianalogikan sebagai suatu proses mekanik. Hal ini terlihat dengan adanya perkembangan industri dan transaksi-transaksi bisnis yang memperkenalkan nilai dan norma baru. Peran "pengubah" tersebut dipegang oleh hakim melalui "interpretasi"

\footnotetext{
${ }^{13}$ Lihat Pound, An Introduction to the Pbilosopby, hal. 87-88.
} 
dalam mengadili kasus yang dihadapinya secara "seimbang". Interpretasi-interpretasi tersebut dapat dilakukan dengan memperhatikan beberapa hal sebagai berikut: (1) Menelaah akibat-akibat sosial yang aktual dari lembaga-lembaga hukum dan doktrin-doktrin hukum, oleh karenanya, ia lebih memandang kepada kerjanya hukum dari pada isi abstraknya; (2) Mengajukan kajian sosiologis berkenaan dengan studi hukum untuk mempersiapkan perundang-undangan. Oleh sebab itu, ia menganggap hukum sebagai suatu lembaga sosial yang dapat diperbaiki guna menemukan cara-cara terbaik untuk meneruskan dan membimbing usaha-usaha sedemikian itu; (3) Mempelajari cara-cara membuat peraturan-peraturan yang efektif dan menitik beratkan pada tujuan sosial yang hendak dicapai hukum, dan bukannya kepada sanksi; (4) Menelaah sejarah hukum sosiologis, yaitu tentang akibat sosial yang ditimbulkan oleh doktrin-doktrin hukum dan bagaimana cara menghasilkannya (5) Membela pelaksanaan hukum secara adil dan mendesak agar ajaran hukum harus dianggap sebagai petunjuk ke arah keadilan bagi masyarakat, dan bukannya sebagai bentuk yang tidak dapat berubah; dan (6) Meningkatkan efektifitas pencapaian tujuan agar upaya mencapai maksud dan tujuan hukum dapat lebih efektif. ${ }^{14}$

Dari keenam program yang dicanangkan Pound tersebut, tak dapat disangkal bahwa dua diantaranya sangat erat hubungannya dengan penilaian teoritis mengenai kenyataan sosial hukum, yakni: telaah tentang akibat sosial hukum dan telaah sosiologis tentang sejarah hukum. Adapun butir lainnya lebih merupakan penggunaan hasil sosiologi hukum untuk pekerjaan seorang hakim atau pembuat undang-undang. Keenam langkah tersebut perlu diperhatikan oleh hakim atau praktisi hukum dalam melakukan "interpretasi" sehingga perlu ditegaskan, bahwa dengan memperhatikan temuan-temuan tentang keadaan sosial masyarakat melalui bantuan ilmu sosiologi, akan terlihat adanya

${ }^{14}$ Lihat Pound, "The Scope and Purpose of the Sociological Jurisprudence", dalam Harvard Lav Revien; vol. 25 (1912), hal. 513-516. 
niali-nilai atau norma-norma tentang "hak" individu yang harus dilindungi, unsur-unsur tersebut kemudian dipegang oleh masyarakat dalam mempertahankan apa yang disebut dengan hukum alam (natural law).

Kalau melihat keberadaan hukum pada masa berkembangnya natural law atau hukum alam, Pound menganjurkan agar konsepsi-konsepsi tentang norma dan nilai yang ditemukan dan disusun dari hasil pelaksanaan interpretasi analogi itu dikembangkan, sehingga dapat dilakukan usaha untuk mengembangkannya ke dalam suatu sistem hukum (legal sistem). Oleh karena itu, sistem hukum yang telah terbentuk itu dapat diaplikasikan ke dalam proses (kegiatan) peradilan (sebagaimana yang dikemukakan Austin). Kegiatan penggalian dan pembentukan sistem hukum, serta pengaplikasiannya di pengadilan, oleh Pound disebut sebagai proses "administrasi hukum". Pound mencoba memperlihatkan bagaimana cara Amerika membentuk sistem hukum dengan mengembangkan administrasi peradilan (administration of justice), untuk sekaligus mengembangkan ilmu hukumnya. Cara yang ditempuh antara lain dengan memperhatikan hal berikut: pertama, pertimbangan-pertimbangan pengadilan dalam menetapkan suatu keputusan yang adil; hukum yang standar seperti halnya dengan standar memelihara, standar keterbukaan, dan standar tentang kepentingan umum; kekuatan ahli hukum untuk mempertahankan keputusan-keputusan yang bersifat umum dengan memperluas penerapan hukum; penemuan hukum terhadap kasus tertentu yang harus diputuskan; metode informal dari suatu administrasi peradilan untuk peradilan rendah; pengadilan administrasi. Kedua, adanya ide dari Austin di atas mengenai proses (kegiatan) peradilan, menimbulkan pertanyaan: Apakah proses peradilan ini termasuk ilmu hukum. Sebab secara kolektif, aktivitas tersebut termasuk peraturan hukum sebagai salah satu sisi dari proses social control, dan aktivitas peradilan itu diarahkan pada penyesuaian hubungan, komponen gagasan yang berlebihan, menjaga kepentingan-kepentingan dengan membuat 
garis pemisah antara masing-masing kepentingan (hak) yang mungkin dapat dipertahankan, sehingga gugatan keinginan yang diajukan dapat memuaskan semua pihak. Ketiga, bila hukum merupakan suatu social control dan sekaligus dapat dijadikan agent of social change, maka hukum memuat prinsip, konsep atau aturan, standar tingkah laku, doktrin-doktrin, dan etika profesi, serta semua yang dijalankan oleh "individu" dalam usaha memuaskan kebutuhan dan "kepentingan" nya. ${ }^{15}$

Hukum sebagai social engineering berkaitan dengan fungsi dan keberadaan hukum sebagai pengatur dan penggerak perubahan masyarakat, maka interpretasi analogi Pound mengemukakan "hak" yang bagaimanakah seharusnya diatur oleh hukum, dan "hak-hak" yang bagaimanakah dapat dituntut oleh individu dalam hidup bermasyarakat. Pound mengemukakan bahwa yang merupakan "hak" itu adalah kepentingan atau tuntutan-tuntutan yang diakui, diharuskan dan dibolehkan secara hukum, sehingga tercapai suatu keseimbangan dan terwujudnya apa yang dimaksud dengan ketertiban hukum. ${ }^{16}$

Apabila program Pound tersebut ditempatkan pada latar belaknag kondisi dan progresifitas masyarakat, maka makna sosiologis hukumnya terlihat pada sifat yang: pertama, lebih diarahkan kepada bekerjanya hukum dari pada isinya yang abstrak. Kedua, Memandang hukum sebagai lembaga sosial yang dapat dikembangkan melalui usaha manusia dan menganggap sebagai kewajiban mereka untuk menemukan cara-cara terbaik dalam memajukan dan mengarahkan usaha sedemikian itu. Ketiga, lebih menekankan pada tujuan-tujuan sosial yang dilayani oleh hukum dari pada sanksinya. Dan keempat, menekankan bahwa aturanaturan hukum itu harus lebih dipandang sebagi pedoman untuk mencapai hasil-hasil yang dianggap adil oleh masyarakat dari pada sebagai kerangka yang kaku. ${ }^{17}$

\footnotetext{
${ }^{15}$ Lihat Ibid., hal. 159.

${ }^{16}$ Lihat Ibid.; lihat juga uraian Pound dalam Tbe Ideal Element, hal. 110-112.

${ }^{17}$ Lihat Pound, "The Scope and Purpose, hal. 645.
} 
Bagi Pound, kekuatan-kekuatan sosial yang membentuk hukum jauh lebih penting dari pada ungkapan-ungkapan hukum secara teknis, sebagaimana terlihat dalam perkembangan yang sama dari Interessen Jurisprudenz pada para ahli hukum Amerika, yakni terhadap latar belakang sistem hukum, pendidikan dan tradisi yang sangat berbeda. Program dan kesimpulan-kesimpulan dari ilmu hukum sosiologis Amerika yang paling lengkap diuraikan oleh Pound. ${ }^{18}$

\section{Perubahan dalam Masyarakat dan Pencapaian Tujuan Hukum}

Lebih jauh, bila membicarakan perubahan dalam masyarakat dan pencapaian tujuan hukum berarti mengkaji perubahan kehidupan sosial dalam masyarakat yang berorientasi kepada proses pembentukan hukum dalam pencapaian tujuannya, oleh karena itu, kata Pound, objek pembahasannya terfokus pada An Engineering Interpretation, ${ }^{19}$ yakni interpretasi terhadap adanya perubahan norma hukum sehingga fungsi hukum sebagai social control dan social engineering dapat terwujud.

a) Konsep dasar an engineering interpretation

Interpretation yang dimaksud oleh Pound adalah sebagai suatu usaha untuk menggali, menemukan, dan memahami nilai-nilai dan norma-norma yang hidup dan berkembang dalam masyarakat, untuk dijadikan sebagai bahan (dasar) pertimbangan dalam menyusun hukum dan menetapkan suatu keputusan dalam menyelesaikan suatu permasalahan yang timbul dalam masyarakat, sehingga terwujud tujuan hukum itu sendiri, yaitu "keadilan" (justice). Adapun engineering yang dimaksud oleh Pound sebagai perubahan-perubahan norma dan nilai-nilai yang terjadi dalam masyarakat seiring

${ }^{18}$ Lihat W. Friedmann, Legal Theory, $4^{\text {Th }}$ Edition (London: Stevens \& Sons Limited, 1960), hal. 293.

${ }^{19}$ Konsep Engineering Interpretation ini diambil dari bab VII buku Roscoe Pound, Interpretation of Legal History, hal. 141-165. 
dengan terjadinya perubahan (perkembangan) kebudayaan dalam masyarakat itu sendiri.

Jadi, yang dimaksud dengan an engineering interpretation adalah usaha-usaha yang dilakukan oleh kalangan pemikir hukum untuk menemukan nilai-nilai dan norma-norma yang ada dalam masyarakat yang selalu mengalami perubahan seiring dengan perkembangan dan pertumbuhan masyarakat, untuk selanjutnya nilai-nilai dimaksud diadaptasikan oleh para legislator dan praktisi hukum dalam menyelesaikan dan mengambil kebijakan terhadap konflik yang terjadi di tengahtengah masyarakat dengan mengacu kepada tercapainya citacita dan tujuan hukum itu sendiri.

b) An engineering interpretation: antara social control dan social engineering

Masalah an engineering interpretation dalam kaitannya dengan fungsi hukum sebagai "kontrol sosial" dan "rekayasa sosial" diuraiakan panjang lebar oleh Pound dalam karyanya Interpretation of Legal History. Terkait dengan hal ini, Pound menyatakan: 'Law must be stable and yet it can not stand still. Hence all thinking about law has struggled to reconcile the conflicting demands of the need of stability and of the need of change... ${ }^{20}$

Dari pernyataan tersebut, jelas sekali bahwa Pound berupaya memperlihatkan usahanya untuk mengungkapkan mengapa hukum itu selalu "dinamis" dengan menelusuri nilainilai dan norma-norma yang ada dan berkembang dalam masyarakat yang selalu berubah-ubah sesuai perkembangan pemikiran masyarakat pada setiap waktu dan tempat. Kedinamisan hukum yang demikian, membuat Pound berasumsi bahwa hukum itu relatif. Yakni, berubah sesuai dengan waktu dan tempat yang sangat erat kaitannya dengan kebudayaan. Meskipun demikian, hukum memiliki sifat

20 Pound, Interprefations of Legal History, hal. 142-143; bandingkan Friedmann, Legal Theory, hal. 32 . 
universalitas karena hanya ada satu ide dari hukum, yaitu "keadilan" (justice). ${ }^{21}$

Menurut Pound, bahwa seiring dengan perubahan hukum dan kebudayaan, bagai dua sisi mata uang yang tidak mungkin dipisahkan antara satu dengan lainnya, maka fungsi dan keberadaan hukum itu akan dapat dilihat dari sudut pandang: 1) pada masa lalu, hukum dipandang sebagai produk atau hasil dari kebudayaan; 2) masa sekarang, hukum dipandang sebagai pemelihara kebudayaan; dan 3) pada masa yang akan datang, hukum dipandang sebagai alat untuk memperkaya kebudayaan. ${ }^{22}$

Dari ketiga sudut pandang di atas, terlihat bahwa aturan hukum (legal order) yang terbentuk dari nilai-nilai dan normanorma yang hidup dan berkembang di tengah-tengah masyarakat, mempunyai tugas atau fungsi ganda, yaitu di satu pihak untuk menjaga nilai-nilai yang sudah ada dan berkembang dalam masyarakat dan di lain pihak untuk membentuk kebudayaan baru dan mengembangkan hak-hak manusia.

Berkaitan dengan fungsi dan keberadaan dari aturan-aturan hukum dimaksud, maka menurut Pound adalah tidak benar kalau hukum itu bersifat "statis", karena hukum abadi hanya ditemui dalam masyarakat yang berhenti perkembangan kebudayaannya atau dalam kebudayaan yang telah "mati".

${ }^{21}$ Dalam kaitannya dengan ini, Pound mencoba mengungkapkan mengapa hukum itu relatif dengan menampilkan pendapat Kohler. Kohler bertitik tolak dari kenyataan bahwa hukum dan kebudayaan itu tidak dapat diceraipisahkan, sehingga relativitas hukum itu disebabkan oleh kebudayaan yang ada dan yang mendukungnya, serta selalu berkembang dan berubah-ubah sesuai waktu dan tempatnya (time and place). Dalam hal ini, Kohler, sebagaimana diungkapkan Pound, menyatakan bahwa meskipun hukum itu relatif, namun tetap memperhatikan tujuan yang hendak dicapai oleh pembuat hukum itu sendiri. Hal itu terlihat dari "Ide Universal" yang dikemukakan sebagai lan of civilization. Selanjutnya dinyatakan bahwa law of civilization ini diterapkan secara berbeda pada setiap kebudayaan. Adapun yang dimaksud dengan "ide universal" tersebut adalah kesebandingan yang merupakan tujuan dan cita-cita hukum di dalam pencapaian "ide" atau "cita-cita" tersebut, yang akan berbeda pada setiap tempat dan waktu. Penjelasan lebih jauh, baca Pound, Interpretation, hal. 142-143.

${ }^{22}$ Lihat Ibid., hal. 143. 
Hal ini dicontohkan oleh Pound dengan aturan-aturan hukum yang terdapat dalam masyarakat Hindu, yang menganut sistem stratifikasi vertikal (kasta-kasta). Aturan hukum yang berlaku dalam masyarakat Hindu menggariskan mereka untuk selalu tetap pada stratanya dengan hak dan kewajiban yang tetap, dan tidak ada kemungkinan terjadinya "mobilisasi sosial" ke strata lainnya. Contoh ini, memperlihatkan bahwa hukum telah menempatkan manusia pada suatu tempat tertentu dan menjaganya untuk tetap di sana.

Selanjutnya, Pound mengemukakan bahwa analogi baru dapat dilakukan oleh hakim jika telah terjadi perubahan sosial sebelumnya. Oleh karena itu, hakim melakukan analogi dalam mengadili kasus-kasus yang dihdapi dengan terlebih dahulu melakukan interpretasi terhadap kasus tersebut, sehingga hakim dapat memutus secara seimbang (balance). Dari interpretasi analogi ini, kemudian Pound menyatakan bahwa filsafat hukum adalah merupakan ilmu pengetahuan tentang perubahan masyarakat. Perubahan masyarakat timbul dari kegiatan-kegiatan yang dilakukan oleh masyarakat itu sendiri atau yang mungkin diperoleh dengan mengatur hubunganhubungan manusia ke arah bentuk yang diingini melalui kegiatan-kegiatan politik dari masyarakat itu sendiri. Jadi, bagi Pound, bahwa selain hukum itu dapat dijadikan sebagai pengatur hubungan masyarakat, juga dapat dijadikan sebagai agent of social change sehingga hukum itu tidak tertinggal dan malah dapat dijadikan sebagai alat untuk "mengubah masyarakat".

\section{Analisis: Problem Kreativitas Hakim Sebagai Pembentuk Hukum}

Hakim merupakan pengemban hukum praktis yang menjadi tulang punggung dalam kegiatan penalaran hukum. Namun demikian, peran hakim dalam suatu tradisi hukum sangatlah berbeda antara satu dengan yang lain. Dalam tradisi 
hukum common law, hakim menempati posisi yang sangat penting dan strategis dalam pembentukan hukum. Karena pada hakekatnya common law adalah sebuah judge made law, artinya hukum yang dibentuk oleh peradilan hakim-hakim kerajaan dan dipraktekkan berkat kekuasaan yang diberikan kepada putusan hakim-hakim. Sistem hukum common law terikat oleh asas Stare decisis yakni asas yang menyatakan bahwa keputusan hakim yang terdahulu harus diikuti oleh hakim yang memutuskan kemudian. ${ }^{23}$

Sementara sistem hukum Eropa Kontinental adalah tradisi hukum yang berkembang di Eopa. Sistem hukum kontinental mengutamakan hukum tertulis berupa aturan perundangundangan sebagai sendi utama sitem hukumnya. Oleh karena itu, di negara-negara yang berada dalam sistem hukum kontinental selalu berusaha untuk menyusun hukum-hukumnya dalam bentuk tertulis bahkan dalam suatu sistematika yang diupayakan selengkap mungkin dalam sebuah kitab undang-undang (kodifikasi).

Pound, seorang ahli dan akademisi hukum yang hidup dan dibesarkan di tengah tradisi hukum common law Amerika, berpendapat bahwa pembuat hukum (termasuk hakim) harus mempelajari efek sosial yang mungkin ditimbulkan oleh institusi dan doktrin hukum, berbanding dengan efek yang mungkin ditimbulkan oleh sarana kontrol atau sarana rekayasa lain yang bukan hukum. Dengan anjurannya yang demikian ini, sesungguhnya Pound telah mengajak khalayak ramai pemerhati kajiankajian hukum Amerika Serikat untuk juga memperhatikan sosiologi hukum.

Satu persoalan yang menarik dikomentari pada cara berpikir ala sociological jurisprudence Pound dengan konsep "law as a tool of social engineering". Konsep ini bisa dikatakan sebagai antonim dari "ber recbt binkt acther de faiten aan" (hukum berjalan tertatih-

${ }^{23}$ John Gillisen dan Frits Gorle, Sejarah Hukum, Suatu Pengantar (Bandung: Refika Aditama, 2005). 
tatih mengikuti kenyataan). Pernyataan yang disebut terakhir menempatkan hukum di belakang kenyataan. Sementara pada konsep "law as a tool of social engineering", hukum justru berada di depan kenyataan. Ini semua berarti, apabila hakimlah yang diminta oleh Pound terutama untuk menjadi "social engineer" jelas seruan ini kurang efektif.

Pound sendiri menginginkan hakim menjatuhkan putusan sesuai dengan "...the demand of justice between the parties and accord with the general reason of the ordinary man". Ditambah lagi dengan fanatisme Pound terhadap sistem common law yang dikenal konsisten menerapkan asas preseden. Jadi, tidak ada yang lebih efektif mengemban tugas perekayasaan sosial (formulating program of action), kecuali melalui jalur undang-undang. Dengan perkataan lain, Pound seharusnya mengalamatkan tugas ini terutama kepada pembentuk undang-undang, bukan terutama kepada pundak hakim.

\section{Krisis Penegakan Hukum di Bawah Bayang-Bayang Intervensi Kekuasaan dan Menjamurnya Mafia Peradilan}

Struktur masyarakat Indonesia yang majmuk tampaknya berimplikasi pada sistem hukum yang ada dan berlaku di Indonesia, yakni sistem hukum yang plural (legal pluralism), di mana hukum jaman kolonial (barat) masih dipertahankan, hukum Agama dan hukum Adat juga diakui dan berlaku, disamping upaya pemerintah untuk membentuk hukum nasional yang cenderung untuk melakukan unifikasi hukum secara sentralistik. ${ }^{24}$

Yang sangat mencolok dalam sistem hukum di Indonesia adalah dominannya peran pemerintah dan parlemen dalam

${ }^{24}$ Seperti diketahui, karakteristik yang menonjol dari kultur hukum yang ada di Indonesia adalah adanya pluralisme hukum (legal pluralism). Secara garis besar ada tiga jenis hukum yang berlaku di Indonesia: hukum Barat, hukum adat, dan hukum Islam. Kodifikasi dan unifikasi hukum dimaksudkan untuk menekan kultur pluralisme hukum yang ada ke tahap yang serendah mungkin dan sebaliknya untuk mendukung terciptanya satu hukum nasional. 
pembentukan peraturan perundang-undangan sementara lembaga peradilan (hakim) tidak lebih dari "pelaksana" atau hakim tidak lebih dari sekedar "mulut" undang-undang. ${ }^{25}$ Akibat dari terlalu dominannya peran pemerintah dan parlemen dalam pembentukan hukum tertulis yang diselimuti kondisi politik yang tidak demokratis di Indonesia, maka telah menghasilkan potret penegakan hukum yang represif. Hukum tidak lagi menampakkan diri sebagai instrumen keadilan dan kemanfaatan tetapi lebih menampakkan diri sebagai instrumen kekuasaan yang otoriter.

Yang perlu dilakukan kedepan agar hukum menjadi instrumen keadilan dan sekaligus untuk mengatasi kelemahan yang terdapat dalam peraturan perundang-undangan adalah dengan memberikan tempat yang sewajarnya kepada peradilan. Dengan catatan hakim dan penegak hukum yang lain diharapkan untuk mengedepankan hati nurani dan keadilan dalam menyelesaikan persoalan-persoalan hukum yang kian dinamis dan kompleks. $\mathrm{Hal}$ ini sejalan dengan fungsi hakim sebagaimana diatur dalam UU No. 4 tahun 2004 yang menyebutkan: "Hakim sebagai penegale bukum dan keadilan wajib menggali, mengikuti dan memabami nilai bukum yang bidup dalam masyarakat".

Dalam kaitan dengan peraturan perundang-undangan, maka hakim dapat menjalankan fungsi-fungsi sebagai berikut: ${ }^{26}$

${ }^{25}$ Menurut Bagir Manan makin besarnya peranan peraturan perundang-undangan terjadi karena beberapa hal: a) Peraturan perundang-undangan merupakan kaidah hukum yang mudah dikenali, mudah diketemukan kembali dan mudah ditelusuri. Sebagai kaidah hukum tertulis, bentuk, jenis dan tempatnya jelas, begitu pula pembuatannya; b) Peraturan perundang-undangan memberikan kepastian hukum yang lebih nyata karena kaidah-kaidahnya mudah diidentifikasi dan mudah diketemukan kembali; c) struktur dan sistematika peraturan perundang-undangan lebih jelas sehingga memungkinkan untuk diperiksa dan diuji baik segi-segi formal maupun materi muatannya; dan d) Pembentukan dan pengembangan peraturan perundang-undangan dapat direncanakan. Faktor ini sangat penting bagi negara yang sedang membangun, termasuk membangun sistem hukum baru sesuai dengan kebutuhan dan perkembangan masyarakat. Lihat Bagir Manan, Dasar-dasar Perundang-undangan Indonesia (Jakarta: IN-HILL-CO, 1992), hal. 8.

${ }^{26}$ Lihat Bagir Manan, "Peran Hakim dalam Dekonstruksi Hukum", dalam I.S. Susanto dan Bernard L. Tanya (Ed.), Wajab Hukum di Era Reformasi (Kumpulan karya Ilmiah Menyambut 70 Tabun Prof. Dr. Satjipto Rabardjo, SH) (Bandung: Citra Aditya Bakti, 2000), hal. 263-264. 
1. Sebagai "dinamisator" peraturan perundang-undangan, hakim dengan menggunakan metode penafsiran, konstruksi dan berbagai pertimbangan sosiolultural berkewajiban menghidupkan peraturan perundang-undangan untuk memenuhi kebutuhan nyata masyarakat.

2. Melakukan "koreksi" terhadap kemungkinan kekeliruan atau kekosongan peraturan perundang-undangan. Hakim wajib menemukan, bahkan menciptakan hukum untuk mengoreksi atau mengisi peraturan perundang-undangan.

3. Melakukan penghalusan terhadap peraturan perundangundangan. Tanpa penghalusan peraturan perundang-undangan akan begitu keras sehingga tidak mewujudkan keadilan dan tujuan tertentu secara wajar.

Untuk mewujudkan konsep hakim sebagai pembentuk hukum melalui yurisprudensi, maka harus ada kemandirian institusi kekuasaan kehakiman, proses peradilan dan juga hakim dalam mengambil keputusan. Kemandirian hakim sangat penting adanya karena hakim secara fungsional merupakan inti dalam proses penyelenggaraan proses peradilan. Indikator mandiri atau tidaknya hakim dalam memeriksa perkara dapat dilihat dari kemampuan hakim menjaga integritas moral dan komitmen kebebasan profesinya dalam menjalankan amanat dari adanya campur tangan dari pihak lain dalam proses peradilan. Dalam perspektif Islam, hakim diperintah untuk memutus perkara secara adil, bijaksana, tegas dan jujur. ${ }^{27}$

Namun sejarah telah membuktikan bahwa kekuasaan kehakiman yang mandiri sebagai sebuah cita-cita yang harus dijunjung tinggi dalam negara hukum Indonesia telah kehilangan elan vitalnya. Independensi kekuasaan kehakiman benar-benar dipertaruhkan dalam proses peradilan yang menyentuh kepentingan kekuasaan. ${ }^{28}$

${ }^{27}$ Lihat QS, Al-Mâidah (5): 42.

${ }^{28}$ Misalnya dalam kasus Imam bin Muhammad Zein, perkara A.M Fatwa, gugatan 
Disamping intervensi kekuasaan eksekutif terhadap kekuasaan kehakiman sebagaimana diungkapkan di atas, kekuasaan kehakiman di dalam menjalankan tugas yudisialnya hingga saat ini masih dijangkiti oleh "penyakit akut" yakni merajalelanya "mafia peradilan".

Ada banyak hasil penelitian yang bisa menunjukkan kepada kita bahwa mafia peradilan memang benar-benar ada. Salah satu hasil penelitian yang dapat kita rujuk adalah penelitian yang dilakukan oleh Mardjono Reksodiputro mengungkapkan bahwa beberapa modus korupsi yang dilakukan oleh kepolisian, kejaksaan dan hakim di pengadilan. Marjdono mengutip istilah yang berkembang di masyarakat "lapor ayam hilang, kambingpun ikut hilang”, maksudnya apabila korban lapor kepada polisi akan keluar lebih banyak uang untuk ikut menanggung biaya operasional polri. ${ }^{29}$

Penelitian yang dilakukan oleh Tim Indonesia Corruption Watch (ICW) memberikan gambaran secara gamlang bagaimana pola kerja/modus operandi para pelaku mafia peradilan. Hasil penelitian tersebut juga mengungkapkan bahwa korupsi di di peradilan tidak hanya terjadi di pengadilan tingkat pertama. Akan tetapi korupsi juga terjadi sampai pada puncak kekuasaan kehakiman yakni MA. ${ }^{30}$

Pemimpin Redaksi Tempo, Goenawan Muhammad dan gugatan perdata rakyat Kedungombo. Loyalitas hakim seolah diperhadapkan dengan independensi kekuasaan kehakiman dalam kasus tersebut. Hakim yang mencoba bersikap netral yang menghadapkan penguasa sebagai tergugat atau tersangka akan mendapatkan hukuman. Hakim Benyamin Mangkudilaga dipindah dari PTUN Jakarta ke PTUN Sumatra Utara setelah menjadi ketua majelis hakim yang memenagkan gugatan Goenawan Muhammad Pemred Majalah Tempo. Ulasan panjang tentang intervensi kekuasaan ekskutif terhadap kekuasaan kehakiman lebih lanjut baca A. Muhammad Asrun, Krisis Peradilan: Mahteamah Agung di Bawab Soebarto (Jakarta: Elsham, 2004).

${ }^{29}$ Lihat Wazingatu Zakiyah dkk., Menyingkap Tabir Mafia Peradilan Jakarta: ICW, 2002), hal. 24-25.

${ }^{30}$ Pola-pola korupsi dalam pengadilan pidana sudah mulai berlangsung pada tahap memasukkan perkara. Agar perkara mendapatkan nomor perkara awal harus memberikan uang pelicin pada bagian registrasi. Sementara pada tahap putusan, putusan dapat dinegoisasi sehingga vonis dapat diatur melalui jaksa atau hakim. Kalau melalui jaksa berarti sudah dalam paket, jaksa akan mengatur semuanya mulai dari tuntutan hingga putusan. Sementara di MA pola kerja mafia peradilan sudah berlangsung pada 
Akibat lebih jauh dari besarnya intervensi eksekutif dan menjamurnya mafia peradilan sebagaimana juga diakui oleh Mahkamah Agung adalah: 1) adanya putusan yang berbeda antara satu majelis hakim agung dengan majlis hakim lain atas suatu permasalahan hukum yang sama dalam suatu waktu tertentu yang berdekatan; 2) adanya putusan yang kurang berkwalitas; 3) adanya putusan yang salah ketik atau bahkan dipalsukan; 4) tidak semua putusan hakim dapat dieksekusi dan lamanya proses berperkara di pengadilan. ${ }^{31}$ Dalam konteks inilah persoalan independensi institusi kehakiman menjadi niscaya untuk diperhatikan dan diupayakan.

\section{E Refleksi Rekonstruktif ke Arah Idealita Pengembangan Kreatifitas Hakim.}

Menempatkan hakim sebagai pembentuk hukum (yurisprudensi) tidaklah selalu berlangsung mudah, karena hakim hanyalah salah satu pengemban hukum praktis yang dalam menjaga independensi dan integritasnya selalu diselimuti berbagai macam kepentingan yang tidak semata-mata tertuju pada cita hukum. Jadi, independensi dan institusi baru belumlah cukup dalam rangka pengembangan kreatifitas hakim sebagai pembentuk hukum karena masalahnya demikian kompleks. Oleh karena itu, menurut hemat penulis, ada beberapa alternatif solusi yang lain yang juga perlu dilakukan, antara lain:

Pertama diperlukan adanya kearifan untuk mau menerima dan tidak menyangkal dari kalangan hakim bahwa korps hakim belum mampu mewujudkan penegakan hukum yang baik. Kedua,

tahapan pendaftaran perkara sampai pada putusan. Pada tahapan putusan berlangsung dalam bentuk Sekjend atau asisten hakim agung agung menghubungi salah satu pihak yang bersengketa dan menawarkan kepada mereka suatu putusan yang dapat memenangkan perkara mereka. Putusan tersebut bisa dibuat sendiri oleh sekjend atau asisten hakim agung. Bisa juga sebenarnya pihak yang berperkara sudah memenagkan perkara akan tetapi putusannya sudah diketahui oleh orang dalam MA, mereka purapura menawarkan jasa untuk memenangkan perkaranya. Lihat ibid, hal. 101.

${ }^{31}$ Lihat buku yang diterbitkan Mahkamah Agung, Cetak Biru Pembarran Mabkamah Agung RI (Jakarta: MA RI, 2003). 
para penegak hukum (terutama hakim) tidak semata-mata melihat hukum dengan kacamata atau paradigma positivist, akan tetapi problem hukum harus dilihat secara komprehensif melalui paradigma non-hukum (sosial) karena kenyataan menunjukkan bahwa problem tidak secara eksklusif dapat diselesaikan dengan ilmu hukum. Pada titik inilah pendidikan hukum harus mendapatkan perhatian serius untuk dibenahi.

Ketiga, perlunya upaya hakim untuk selalu meningkatkan kreatifitasnya guna menemukan dan menggali hukum-hukum baru. Hal ini mengingat bahwa hukum tidak selalu merupakan barang jadi yang siap pakai, melainkan harus ditemukan. Dalam banyak hal penegakan dan pelaksanaan hukum tidak hanya sekedar penerapan hukum, tetapi juga sering merupakan penemuan hukum (rechtsvinding). Menurut para ahli hukum, oleh karena kegiatan kehidupan manusia tidak terbilang banyaknya, suatu undang-undang, betapapun sempurna dan komplitnya ketika dibuat, selalu segera setelah diundangkannya akan dirasa kurang atau terdapat beberapa ketidakjelasan maksudnya. Oleh karena itu, penemuan hukum merupakan suatu keniscayaan dalam setiap sistem hukum, khususnya oleh para hakim.

Keempat, kesejahteraan hakim harus mendapatkan perhatian yang khusus dari pengambil keputusan. Setelah kesejahteraan dikedepankan maka harus diikuti dengan pembersihan secara internal. Kelima, perlunya mendorong gagasan "Penegakan Hukum Progresif", yakni gagasan bahwa menjalankan hukum bukan sekedar menurut kata-kata hitam-putih dari peraturan (according to the letter), melainkan menurut semangat dan makna yang lebih dalam (to the very meaning) dari undang-undang atau hukum. Inilah yang disebut, meminjam bahasa Satjipto Raharjo, sebagai penegakan hukum tidak hanya dengan kecerdasan intelektual melainkan juga dengan kecerdasan spiritual $^{32}$. Dan

${ }^{32}$ Lihat Satjipto Raharjo, "Eksaminasi Publik Sebagai Manifestasi Kekuatan Otonomi Masyarakat dalam Penyelenggaraan Hukum," dalam Ekesaminasi Publik Jakarta: ICW, 2003), hal.35-58. 
keenam, perlunya partisipasi publik dalam pembenahan institusi kehakiman. Institusi peradilan selama ini terkesan menutup diri terhadap publik. Peradilan harus terbuka terhadap publik. Bukankah dua abad yang lalu Jeremy Bentham pernah menyatakan: "...In the darkeness of secregy, sinister interest and evil in every shape have full swing. Only in proportion as publicity has places can any of the checks aplicable to judicial in justice operate. Where there is no publicity there is no justice. Publicity is the very soul of justice. It is the keenest spur to exertion and the surest of all guard against improbity. It keeps the judge bimself while trying under trial'33

\section{F. Penutup}

Bercermin dari pemikiran yang diajukan Roscoe Pound, maka betapa peran yang harus dimainkan hakim sebagai kreator pembentuk hukum harus didasarkan pada prinsip-prinsip keadilan karena putusan hakim memiliki dampak sosial, politik, dan budaya yang cukup luas.

Namun penempatan hakim sebagai pembentuk hukum (yurisprudensi) tidaklah selalu berlangsung mudah, karena hakim hanyalah salah satu pengemban hukum praktis yang dalam menjaga independensi dan integritasnya selalu diselimuti oleh kepentingan hakim dan kepentingan eksternal yang tidak sematamata tertuju pada tujuan hukum menuju keadilan, kemanfaatan dan kepastian. Di sinilah pentingnya menjaga independensi institusi kehakiman, termasuk independensi hakim sebagai pembentuk hukum. Dengan berbekal independensi dan jauh dari intervensi pihak manapun, eksekutif khususnya, hakim akan lebih dapat mengembangkan kreativitasnya dalam menjalankan profesinya. Sehingga hakim akan bisa menjadikan hukum, tidak hanya sekedar sebagai sarana untuk mempertahankan stabilitas (law as a tool of social control) tapi juga sebagai sarana untuk melakukan perubahan masyarakat (law as a tool of social engineering).

\footnotetext{
${ }^{33}$ Sebagaimana dikutip oleh S. Assegaf dan Josi Khatarina, Membuka Ketertutupan Pengadilan (Jakarta: Leip, 2005) 1.
} 


\section{DAFTAR PUSTAKA}

Asrun, Muhammad. Krisis Peradilan: Mabkamah Agung di Bawah Soebarto. Jakarta: Elsham, 2004.

Assegaf, S. dan Josi Khatarina. Membuka Ketertutupan Pengadilan. Jakarta: Leip, 2005.

David, Rene. Major Legal System in The World Today. London: Stevans \& Sons, 1995.

Frank, Jerome. Law and the Modern Mind. Garden City, NY: Anchor Books, 1960.

Friedmann,W. Legal Theory, $4^{\text {th }}$ Edition. London: Stevens and Sons Limited, 1960.

Gifis, Steven H. Law Dictionary. New York: Barron's Educational Series, Inc., 1984.

Gillisen, John dan Frits Gorle. Sejarah Hukum: Suatu Pengantar. Bandung: Refika Aditama, 2005.

Gurvitch, Georges. Sosiologi Hukum, terj. Suntri Mertodipuro \& Moh. Radjab. Jakarta: Brhatara, 1988.

Hamilton, Neil dan Mathias Alfred Jaren. "Introduction to the Transaction Edition," dalam Pound, An Introduction to the Philosopby of Law, New Edition. New Brunswick \& London: Transaction Publishers, 1999.

Hernawan, Ari. "Reposisi Fungsi Advokad dalam Proses Penegakan Hukum." Dalam Asy-Syir'ab, 36, 2 (2002). 
Huijbers, Theo. Filfasat Hukum dalam Lintasan Sejarah. Yogyakarta: Kanisius, 1982.

Johnson, Alvin S. Sosiologi Hukum, terj. Rinaldi Simamora. Jakarta: PT. Rineka Cipta, 2004.

Manan, Bagir. Dasar-Dasar Perundang-Undangan Indonesia. Jakarta: IN-HILL-CO, 1992.

- "Peran Hakim dalam Dekonstruksi Hukum," dalam I.S. Susanto dan Bernard L. Tanya (ed.), Wajah Hukum di Era Reformasi (Kumpulan karya Ilmiah Menyambut 70 Tabun Prof. Dr. Satjipto Rahardjo, SH). Bandung: Citra Aditya Bakti, 2000.

Paton, G.W. A Test-Book of Jurisprudence. London: Oxford University Press, 1951.

Pound, Roscoe. The Spirit of the Comman Law, New Edition. New Brunswick \& London: Transaction Publishers, t.t. . 'Do We Need a Philoshopy of Law?", Columbia Law Review, 5 (1905).

. "Excecutive Justice," American Law Register, 46 (1907).

. "Suprious Interpretations," Colombia Law Review, 7 (1907), 379.

- "The Scope and Purpose of Sociological Jurisprudence," Harvard law Review, 24 (1911).

. "The Need of Sociological Jurisprudence," Green Bag, 19 (1907). 
- "The Scope and Purpose of Sociological Jurisprudence", dalam Ervin H. Pollack, Jurisprudence: Principles and Applications. T.tp.: the Ohio State University Press, 1979.

The Task of Law (Tugas Hukum), terj. Muhammad Radjab. Jakarta: Bhratara, 1965.

An Introduction to the Pbilosopby of Law. New Brunswick \& London: Transaction Publishers, 1999.

- _ - "The Scope and Purpose of the Sosiological Jurisprudence," dalam Harvard Law Review, vol. 25 (1912).

. "In My Philosophy of Law," dalam Ervin H. Pollack, Jurisprudence: Principles and Applications. Ttp.: the Ohio State University Press, 1979.

Presser, Stephen B. "Foreword", dalam Roscoe Pound, The Ideal Element in Law. Indiana Polis, Liberty Fund, 2002.

Rahardjo, Satjipto. Sosiologi Hukum: Perkembangan, Metode, dan Piliban Masalah. Surakarta: Muhammadiyah University Press, 2004. . Ilmu Hukum. Bandung: Alumni, 1986.

"Eksaminasi Publik Sebagai Manifestasi Kekuatan Otonomi Masyarakat dalam Penyelenggaraan Hukum” dalam Eksaminasi Publik. Jakarta: ICW, 2003.

Sayre, Paul. The Life of Roscoe Pound. Iowa: State University of Lowa, 1984. 
Warassih, Esmi. Pemberdayaan Masyarakat Dalam Mewujudkan Tujuan Hukum (Proses Penegakan Hukum dan Persoalan Keadilan). Semarang: Badan Penerbit Universitas Diponegoro, 2001.

Widgor, David. Roscoe Pound: Philosopher of the Law. Westport: Greenwood Press, 1974.

Zakiyah, Wazingatu dkk. Menyingkap Tabir Mafia Peradilan. Jakarta: ICW, 2002.

Mahkamah Agung. Cetak Biru Pembaruan Mableamab Agung RI. Jakarta: MA RI, 2003. 